\title{
The Application of Satellite Imagery in Surface Water/Lake Modelling: A Review of Previous Studies on Lake Tana and Its Basin
}

\author{
Nuredin Teshome ${ }^{1, ~ *}$, Gizaw Mengistu Tsidu², Bisrat Kifle ${ }^{3}$ \\ ${ }^{1}$ Space Science and Application Development, Ethiopian Space Science and Technology Institute, Addis Abeba, Ethiopia \\ ${ }^{2}$ Earth and Environmental Science, Faculty of Science, Botswana International University of Science and Technology, Palapye, Botswana \\ ${ }^{3}$ Urban Environment and Climate Change Management, Urban Development and Engineering, Ethiopian Civil Service University, Addis \\ Ababa, Ethiopia
}

Email address:

nuredin.t@yahoo.com (N. Teshome)

${ }^{*}$ Corresponding author

\section{To cite this article:}

Nuredin Teshome, Gizaw Mengistu Tsidu, Bisrat Kifle. The Application of Satellite Imagery in Surface Water/Lake Modelling: A Review of Previous Studies on Lake Tana and Its Basin. Science Research. Vol. 8, No. 3, 2020, pp. 73-83. doi: 10.11648/j.sr.20200803.12

Received: December 25, 2019; Accepted: May 26, 2020; Published: June 17, 2020

\begin{abstract}
Satellite images give a synoptic view of target areas, measure target surface changes and provide the information needed for hydrological studies, river or Lake Basin management, water disaster prevention, and water management. Lake Tana is located at an altitude of $1830 \mathrm{~m}$ and latitude longitude of $11.27^{\circ} \mathrm{N}$ and $37.10^{\circ} \mathrm{E}$. The lake is the source of the Blue Nile River and it is the largest lake in Ethiopia with a surface area of $3,150 \mathrm{~km}^{2}$, a maximum length and width of 78 and $68 \mathrm{~km}$ respectively. In the past, several studies have been published on Lake Tana and its basin in a scattered manner. This necessitates state of the art review that highlights achievements, models, algorithms, and identify gaps in knowledge. Different types of hydrological models have been applied. The majority of the recent studies utilized simple conceptual and statistical approaches for trend analysis and water balance estimations, mainly using rainfall, temperature and evapo-transpiration data. To a greater extent, recent studies have used advanced semi-physically or physically based distributed hydrological models driven by high resolution temporal and spatial data for diverse applications. A review of the methods used and the role of satellite remote sensing in this regard to understand the hydrology of Lake Tana and its basin are presented.
\end{abstract}

Keywords: Satellite Imagery, Surface Water/Lake Modeling, Lake Tana

\section{Introduction}

Ethiopia is located in East Africa and covers a total surface area of 1.1 million square kilometers. Water bodies cover only $0.7 \%$ of the area of the country with 10 lakes. Most of them are located in the Rift Valley, and together they have a total surface area of 7,500 $\mathrm{km}^{2}$. By far the largest water body is Lake Tana (50\% of the total lakes area) located outside the Rift Valley on the northwestern plateau [23]. It is located at an altitude of $1830 \mathrm{~m}$ and $11.27^{\circ} \mathrm{N}$ and $37.10^{\circ} \mathrm{E}$ of Ethiopia and it is the source of the Blue Nile River and it is the largest lake in Ethiopia with a surface area of $3,150 \mathrm{~km}^{2}$, a maximum length and width of 78 and $68 \mathrm{~km}$ respectively. A bathymetric map produced by $[64,73]$ shows a gentle slope of the saucer shaped Lake Bottom, which is covered with soft sediments. The shallow littoral zone (depth $0-4 \mathrm{~m}$ ) is relatively small, ca. $10 \%$ of the total surface area of the lake. The sub littoral zone contains no macrophytes and occupies ca. $20 \%$ of the lake area (depth $4-8 \mathrm{~m}$ ), whereas the oceanic zone is $70 \%$ of the lake surface area and relatively deep (depth 8 - $14 \mathrm{~m}$ ). Lake Tana has been formed because of damming by lava flow during the Pliocene [63] but the formation of the depression itself started in the Miocene [21].

\section{Review on Satellite Image Processing Application}

Hydrological data collection remains a difficult task now a day due to non availability of measurement devices, 
inaccessibility of the terrain and limitations of space/time [57, 12]. A good alternative to overcome these difficulties is the use of satellite remote sensing images, which can give a synoptic view of target areas and measure target surface changes and therefore provide the information needed for hydrological studies, river/ lake basin management, water disaster prevention and water management, etc [19]. Lake Tana receives about $90 \%$ of the inflow from the four rivers. The local and regional groundwater inflow contributes only $3 \%$ and $7 \%$, respectively [16]. The lake is geologically dammed by quaternary and tertiary basalts in the south and western part where the out flowing Blue Nile River drains out [50]. The damming has cut of any oozing out flow which simplifies modeling of the lake stage [44]. The climate of Lake is characterized by a major rainy season (kiremt), during June - October, short rain season during February and

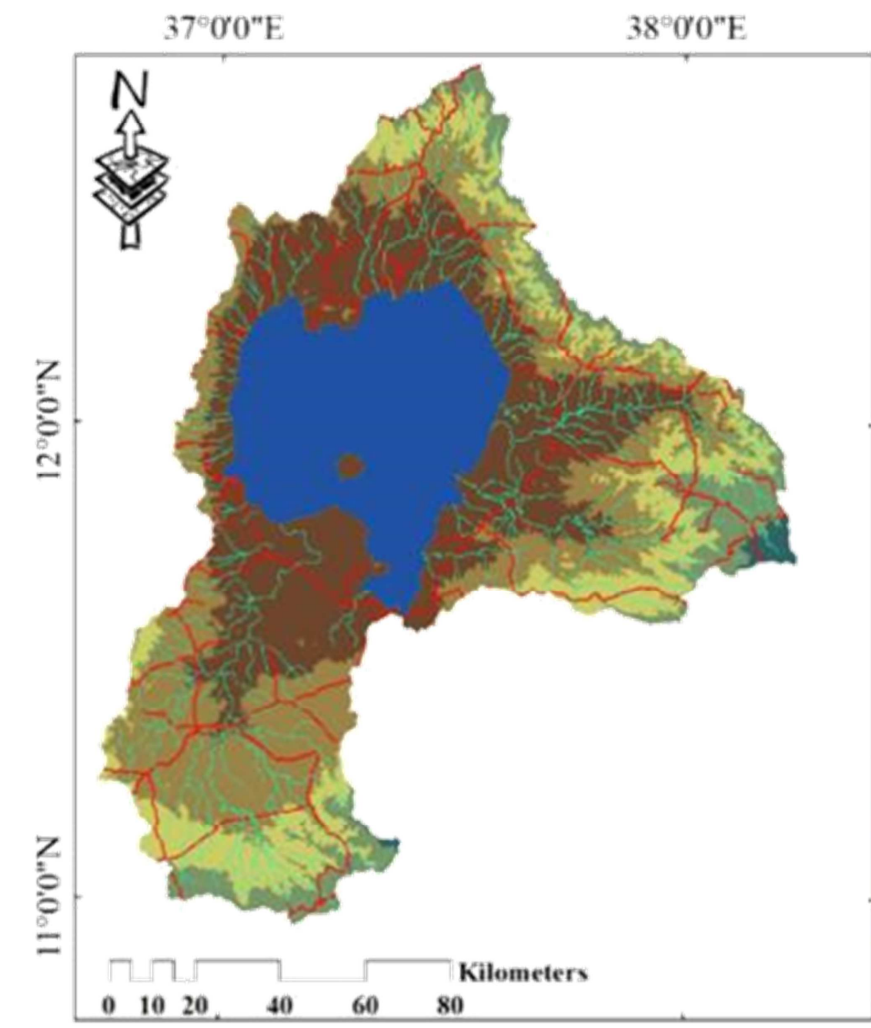

dry season November to January. The average annual rainfall in the lake area over $1997-2000$ was $1418 \mathrm{~mm}$. The water level of the lake fluctuates with rainfall up to $1 \mathrm{~m}$. Maximum water temperature, as a monthly average, ranged between $21^{\circ} \mathrm{C}$ and $26^{\circ} \mathrm{C}$ over $1997-2000$. Water temperatures varied between narrow limits, with lowest values in January, a sharp increase in February, peak values in May and sharp decline with the big rains in June - July [23]. Several methods have been used to delineate the hydrological extent from satellite data; such as the utilization of multi-polarized advanced satellite images, application of a statistical active control model, multi-temporal image enhancement and differencing, histogram thresholding/clustering, radiometric thresholding, pixel based segmentation, and use of artificial neural networks [67].

Figure 1. Location map of Lake Tana basin [51].

Table 1. Some satellite missions and sensors used for hydrological studies.

\begin{tabular}{lll}
\hline Satellite mission & Sensor & Data Record Period \\
\hline Nimbus -7 & Coastal Zone Color Scanner (CZCS) & October 1978 to June 1986 \\
Adeos & Ocean Color and Temperature Scanner (OCTS) & October 1996 to June 1997 \\
OrbView2 & Sea wifs & August 1997 to February 2011 \\
Envi sat & Meris & March 2002 to May 2012 \\
Terra & Moderate Resolution Imaging Spectro radiometer (MODIS) & December 1999 to present \\
Aqua & MODIS & July 2002 to PRESENT \\
ISS & Hyper spectral Imager for the Coastal Ocean (HICO) & September 2009 to September 2014 \\
SNPP & Visible Infrared Imaging Radiometer Suite (VIIRS) & October 2011 to present \\
COMS & Geostationary Ocean Color Imager (GOCI) & May 2011 to PRESENT \\
SACD & AQUARIUS & June 2011 to June 2015 \\
Sentinel3 & Ocean and Land Color Instrument (OLCI) & February 2016 to present \\
\hline
\end{tabular}




\section{Scope of Studies on Lake Tana}

Some researchers have evaluated the temporal trajectory change of the lake surface area eg. [89], the majority of the investigations were on the exploration of seasonal and annual trends of rainfall in the Lake Tana basin (LTB) and their connections with global sea surface temperatures (SSTs) e.g.
$[43,83]$, the evaluation of hydrological impacts of climate and LULC changes on the water balance of the Lake was also made in several studies e.g. $[65,61]$, while others focused on simulating water balance at a daily time step by accounting for all inflow and outflow processes of lake Tana e.g. $[14,72]$. The comprehensive list of studies and their objectives are given in Table 2.

Table 2. Overview on previous studies and their objectives.

\begin{tabular}{|c|c|c|}
\hline Article & Study objectives & References \\
\hline $\begin{array}{l}\text { Temporal and special phytoplankton biomass dynamics in } \\
\text { southern Gulf of LakeTana, North western Ethiopia }\end{array}$ & $\begin{array}{l}\text { Determining the special and temporal variation of phytoplankton biomass } \\
\text { of the gulf (southern gulf of lake Tana) }\end{array}$ & [37] \\
\hline $\begin{array}{l}\text { Temporal Trajectory Analysis of Lake Surface Area: Case } \\
\text { study on Lake Tana, Ethiopia }\end{array}$ & $\begin{array}{l}\text { Evaluating the temporal trajectory change of the lake surface area of lake } \\
\text { Tana }\end{array}$ & [89] \\
\hline $\begin{array}{l}\text { Analysis of Rainfall Trends and Its Relationship with SST } \\
\text { Signals in the Lake Tana Basin, Ethiopia }\end{array}$ & $\begin{array}{l}\text { Exploring seasonal and annual trends of rain fall in lake Tana basin and } \\
\text { their tele- connection with sea surface temperature }\end{array}$ & [83] \\
\hline $\begin{array}{l}\text { Hydrological Impact Assessment of Climate Change on Lake } \\
\text { Tanas Water Balance, Ethiopia }\end{array}$ & $\begin{array}{l}\text { Evaluating the hydrological impacts of climate change on the water } \\
\text { balance of Lake Tana in Ethiopia. }\end{array}$ & [65] \\
\hline $\begin{array}{l}\text { Mapping the vegetation of the Lake Tana basin, Ethiopia, using } \\
\text { Google Earth images }\end{array}$ & $\begin{array}{l}\text { Mapping the vegetation of Lake Tana basin through visual interpretation } \\
\text { using high spatial resolution images to provide detailed information of the } \\
\text { actual vegetation state for planning conservation and restoration. }\end{array}$ & [77] \\
\hline $\begin{array}{l}\text { Estimation of Lake Outflow from the Poorly Gauged Lake } \\
\text { Tana (Ethiopia) Using Satellite Remote Sensing Data }\end{array}$ & $\begin{array}{l}\text { Investigating the water balance of lake Tana at monthly and annually time } \\
\text { scale. }\end{array}$ & [28] \\
\hline $\begin{array}{l}\text { Water Hyacinth Coverage Survey Report On Lake Tana } \\
\text { Biosphere Reserve. Technical Survey Report Series } 2\end{array}$ & To know and report the water hyacinth coverage of lake Tana & [8] \\
\hline $\begin{array}{l}\text { Stage level, volume, and time frequency information content of } \\
\text { Lake Tana using stochastic and wavelet analysis methods }\end{array}$ & Simulating the lake level, specifically extreme events of the lake variation. & [14] \\
\hline $\begin{array}{l}\text { Hydrological Modelling in the Lake Tana Basin, Ethiopia } \\
\text { Using SWAT Model }\end{array}$ & $\begin{array}{l}\text { Testing the performance and feasibility of the SWAT mode for prediction } \\
\text { of stream flow in the Lake Tana Basin. }\end{array}$ & [74] \\
\hline
\end{tabular}

\section{Data and Methods Employed in Past Studies}

\subsection{Data}

Observations are from many different sources, including satellites, ships, ground stations, and radar. Currently, earth system research laboratory, physical sciences division (PSD) makes available these reanalysis datasets to the public. Reanalysis is a method to reconstruct the past state of the atmosphere and oceans in a coherent way by combining available observations with numerical models [7]. The Land sat satellites and other remote sensing data with high spatial resolution and frequent coverage have been widely used for a variety of space and land surface dynamics, monitoring applications such as change detection [22, 86, 18, 56], land cover classification $[46,88]$, biomass estimation $[90,55]$, leaf area index retrieval $[17,30]$, vegetation phonology monitoring [75], and drought monitoring [32]. The Land sat satellites and remote sensing data are needed for monitoring heterogeneous landscapes or rapid surface changes [91]). Seasonal time series data from satellites are highly desired by researchers since they contain the temporal aspects of natural phenomena on the land surface, which are extremely helpful for discriminating different land cover types [92], monitoring vegetation dynamics [75], estimating crop yields [48], assessing environmental threats [34], exploring human nature interactions [93], and revealing ecology climate feedbacks [68]. For analyzing lake Tana and its basin many types of data were employed to assess the physical, climatologically, hydrological and environmental phenomena of the lake and its basin, such as monthly rainfall and precipitation data e.g. [28], weather and soil data e.g. [74], and surveying and GPS data e.g. [8]. Table 3 lists the data types of some selected studies of Lake Tana and its basin.

Table 3. The data used by some researchers on Lake Tana and its basin.

\begin{tabular}{|c|c|c|c|}
\hline Data used & Study period & Focus area & References \\
\hline Rain fall data from NMA and SST data from NOAA & $1979-2015$ & Lake Tana basin (LTB) & [83] \\
\hline Daily records of metrological and hydrological data & $1981-2010$ & $\begin{array}{l}\text { Lake Tana basin (Adet, Bahir Dar, Dangila, } \\
\text { Debre Tabor and Gondar) }\end{array}$ & {$[65]$} \\
\hline Global Circulation Model (GCMs) data & $2010-2100$ & $\begin{array}{l}\text { Lake Tana Basin (Gilgel Abay River, Upper } \\
\text { Blue Nile Basin) }\end{array}$ & {$[26]$} \\
\hline Land sat images, lake level, rain fall, temperature and population & $\begin{array}{l}\text { for the last } 30 \\
\text { years }\end{array}$ & $\begin{array}{l}\text { Gilgel Abbay Catchment from southern part of } \\
\text { Lake Tana }\end{array}$ & [61] \\
\hline $\begin{array}{l}\text { Daily climate projections data from global climate models (GCMs) and } \\
\text { hydrological changes data using the Soil and Water Assessment Tool }\end{array}$ & $1961-2000$ & Lake Tana Basin & [74] \\
\hline
\end{tabular}




\begin{tabular}{|c|c|c|c|}
\hline Data used & Study period & Focus area & References \\
\hline \multicolumn{4}{|l|}{ (SWAT) } \\
\hline Monthly rain fall data and monthly precipitation data & & Lake Tana & [28] \\
\hline $\begin{array}{l}\text { Time series of monthly flow data, daily flow series dataturbine } \\
\text { discharge data }\end{array}$ & $1959-2006$ & Lake Tana basin & [58] \\
\hline High spatially resolution images and field survey data & & Lake Tana basin & [77] \\
\hline Average annual and daily rain fall data & $1994-2010$ & Source of the blue Nile river (Lake Tana basin) & [84] \\
\hline Satellite images and filed observation data & 1985 and 2011 & East of lake Tana (Tana mitsil ikebele) & [36] \\
\hline Satellite images and filed observation data & $1973-2011$ & Lake Tana basin & [69] \\
\hline Black and white photography and land sat satellite images & $1957-2014$ & Lake Tana water shed (Gelda catchment) & [29] \\
\hline Aerial photography and multispectral spot images & $1957-2005$ & Lake Tana basin (Gumera watershed) & [85] \\
\hline $\begin{array}{l}\text { Farmer interview, remote sensing images and current gully } \\
\text { measurement }\end{array}$ & $2005-2008$ & Debremawi watershed (south of lake Tana) & [79] \\
\hline Hourly rain fall data and cloud temperature indices & & Lake Tana basin & [43] \\
\hline Satellite images, Climatic data and TM data & $1985-2011$ & Angerb watershed (upper Tana basin) & [59] \\
\hline Land sat satellite images, temperature and rainfall data & $1973-2008$ & Gilgel Abbay catchment of lake Tana & [62] \\
\hline
\end{tabular}

\subsection{Spatial and Temporal Precipitation Data Analysis}

Precipitation is a major component of the water cycle and is responsible for depositing approximately $505000 \mathrm{~km}^{3}$ (or on average $990 \mathrm{~mm}$ ) of the freshwater on the plan [70]. It is one of the major water balance components of the global water budget. Although the spatial and temporal variability of precipitation is important, unless large numbers of rain gauge stations are available, capturing variability is difficult $[13,66]$.
Moreover, ground based rainfall observation station networks are often unevenly and sparsely distributed in developing countries [49]. The monitoring of precipitation by satellites and that at weather stations has different spatial and temporal characteristics [87]. The TRMM precipitation had difficulties in detecting precipitation at high elevations, especially in the rain shadows [5]. However, this effect may have been somehow overcompensated by the TMI or IR component in the 3B42 V5 dataset [87].

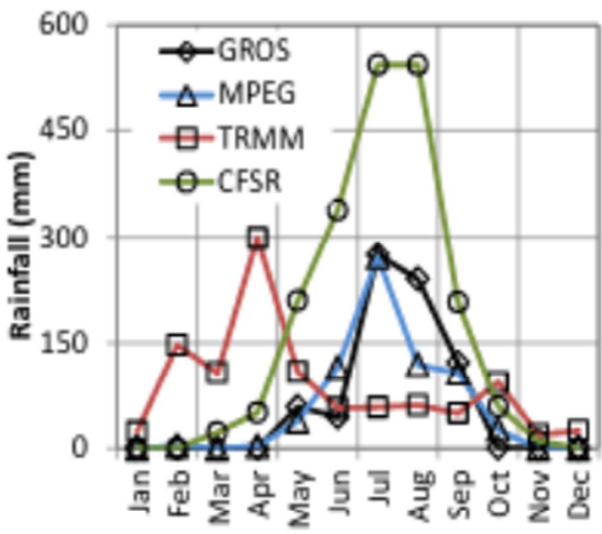

(A) Gorgara station

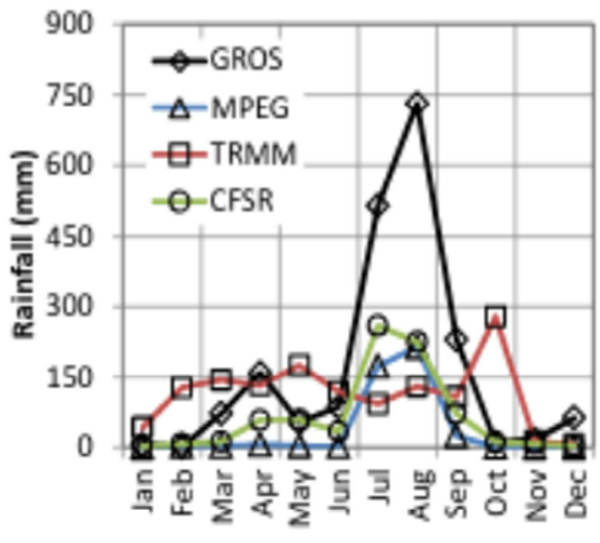

(B) Agre Genet station

Figure 2. Temporal distribution of gauged rainfall and satellite rainfall estimation from the Tropical Rainfall Measuring Mission (TRMM), Multi-Sensor Precipitation Estimate Geostationary (MPEG) and Climate Forecast System Reanalysis (CFSR) for Gorgara and Agre Genet stations (year: 2010) [84].

\subsection{Big Data Approach}

Earth observation data, admitting satellite images, are an example of a big data source which can be obtained at no cost, for a long time series, and used to develop statistics and indicators to measure sustainable development [42]. In 2017, the United Nations project team on satellite imagery and geospatial data published a report on the feasibleness of using earth observation data to produce official statistics, including statistics relevant to SDGs such as agricultural indicators and land cover
[42]. There are many useful resources on the topic of earth observation data for official statistics and SDGs, including satellite earth observations in support of the SDGs [45], Earth observation for water resources management [33], statistical analyses of satellite images, such as land cover, can be apply to Sustainable Development Goals (SDGs). The group on earth observation (GEO) has identified that several SDGs can be measured at some level using earth observation data [20]. 

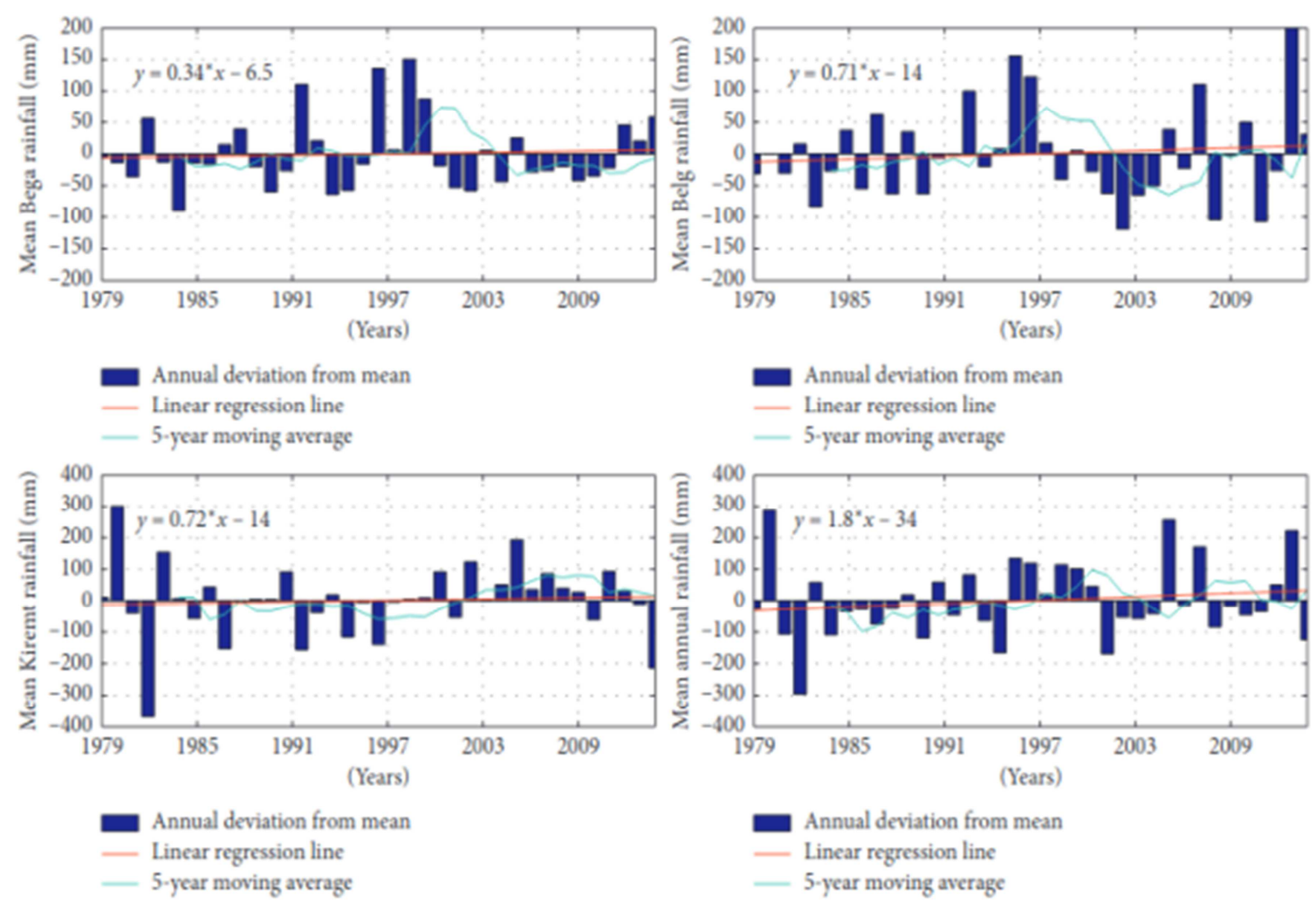

Figure 3. Mean seasonal and annual rainfall and equivalent linear regression trend line and 5 year moving average line plotted for the different aggregated station data sets. (a) Bega. (b) Belg. (c) Kiremt. (d) Annual [83].

\subsection{LULC Change Analysis}

Land use/cover is two separate nomenclatures which are often used interchangeably [27]. Land cover adverts to the physical characteristics of earth's surface, captured in the distribution of vegetation, water, soil and other physical features of the land, including those created solely by human activities. On the other hand, land cover is defined by the attributes of the earth's land surface captured in the distribution of vegetation, water, desert, ice and the immediate subsurface, including biota, soil, topography, surface and groundwater and it also includes those structures created solely by human activities such as mine exposures and settlement [52] and [9]. Land use and land cover (LU/LC) change is a locally pervasive and globally significant ecological trend and has become an event of paramount importance to the study of global environmental change [39]. LU/LC change is progressively accredited as an important driver of environmental change on all spatial and temporal scales [81]. Land use/land cover change has been also creditworthy for altering the hydrologic response of watersheds leading to impacting river flows [40]. LU/LC complains in significantly to earth atmosphere interactions, forest fragmentation, and biodiversity loss. Thus, it has become one of the major issues for environmental change monitoring and natural resource management. That is why LU/LC change and its impacts on terrestrial ecosystems including forestry, agriculture, and biodiversity have been identified as high priority issues in global, national, and regional levels [31]. Land use/cover changes are the major issues and challenges for the eco-friendly and sustainable development for the economic growth of any area. With the population explosion, human activities such as deforestation, soil erosion, global warming, and pollution are very harmful to the environment. This causes land use/cover changes with the demand and supply of land in different activities. Change detection in land use and land cover can be performed on a temporal scale such as a decade to assess landscape change caused due to anthropogenic activities on the land [41]. Land Use/Land Cover (LULC) change is one of the major worldwide environmental gainsays to humanity. It significantly affected hydrological response [82, 78], ecosystem services [53], and climate processes. The expansion of agriculture leads to a significant change in runoff and sediment load [38,60]. Significant variation of evapo-transpiration has occurred due to LULC and leaf area index change [54]. Land use change can direct to a significant change in groundwater recharge and base flow [10] flood frequency and interval [4], peak runoff [2], and total suspended sediment and nutrient tightness [47]. Moreover, the land use change affects local, regional and global climate system [24], and degrades the health of a wetland ecosystem [3]. Land use change and climate changes could have interactive effects on the environment [11]. LU/LC dynamics is one of the major environmental troubles in Ethiopia. In congress to this, recent watershed based LULC studies of lake Tana depicted that land cover change is barbarous and there has been agricultural land size expansion at the expense of natural vegetation cover lands and marginal areas without any appropriate conservation measures [76, 6, 25, 35]. 
Similarly LU/LC dynamics of lake Tana basin shows that forest, shrub and grazing lands revealed negative rate of change between 1985 and 2011 while areas of cultivated land
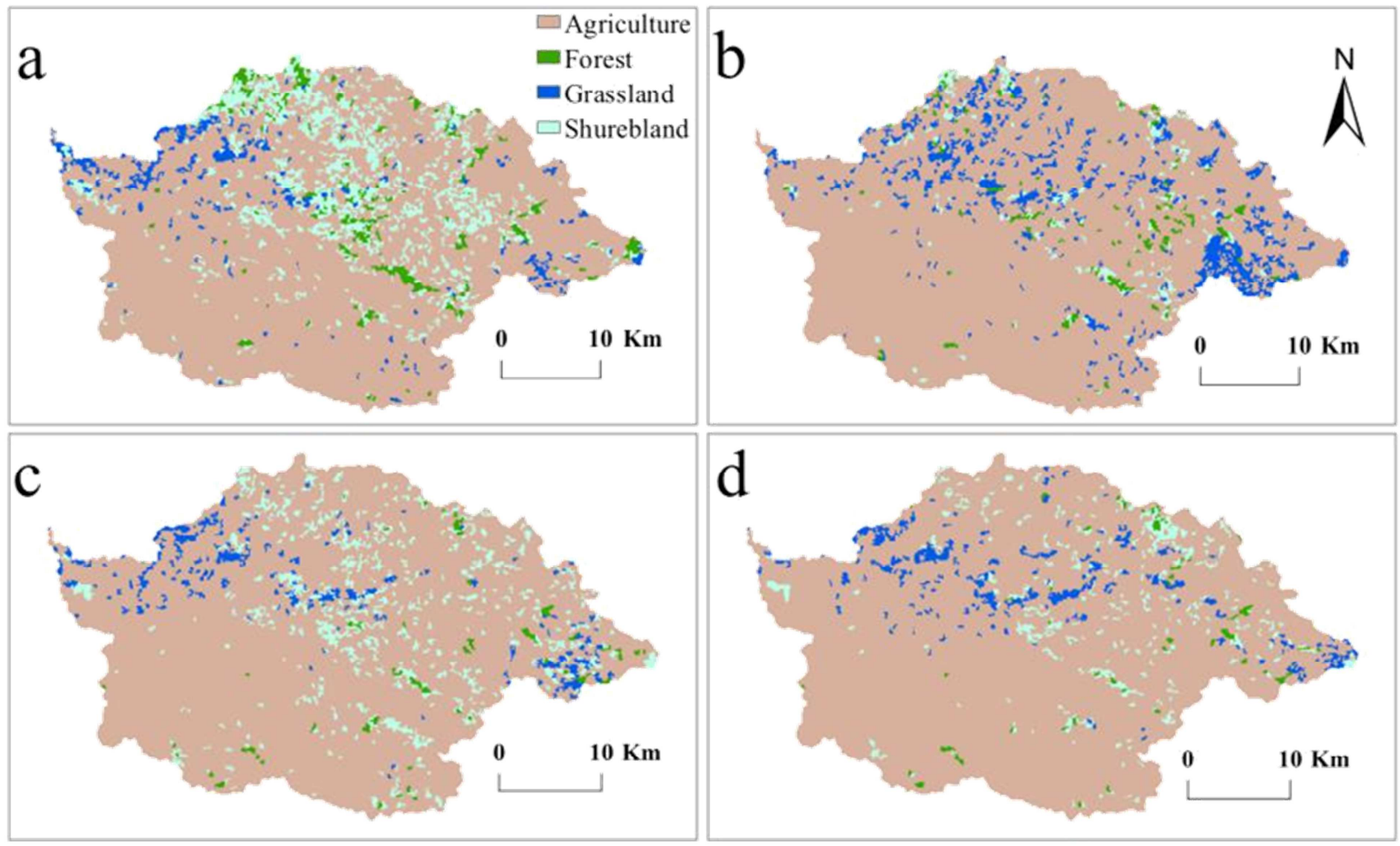

Figure 4. Land use land cover maps of the Gummara watershed: land uses for a) 1985, b) 1995, c) 2005, and d) 2015 [80].

\subsection{Advances in Models / Algorithms Used for the Studies}

Different scholars applied different models to study lake Tana and its basin such as stochastic and wavelet analysis methods [14], statistical measures (coefficient of determination $\left(\mathrm{R}^{2}\right)$, multiplicative bias (bias) and root mean square error (RMSE) [84], hybrid image classification method (unsupervised and maximum likelihood supervised

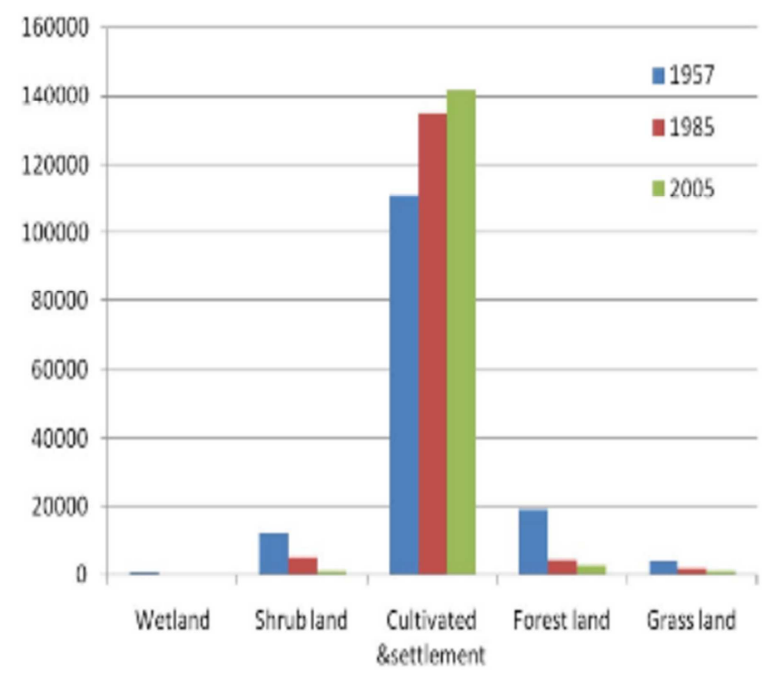

and degraded land was increased accounted for $66.73 \%$ and $2.15 \%$ respectively in 2011 [36]. classification algorithm) [36] and [40], a conceptual water balance based model (HBV96 model) [72], land use/cover trend analysis [85], linear time series analysis (Linear regression) and supervised classification [62], Swat and Digital Elevation Model [74], etc. For more exhaustive descriptions of the algorithms or models the readers are directed to the original articles cited above and in Table 4.

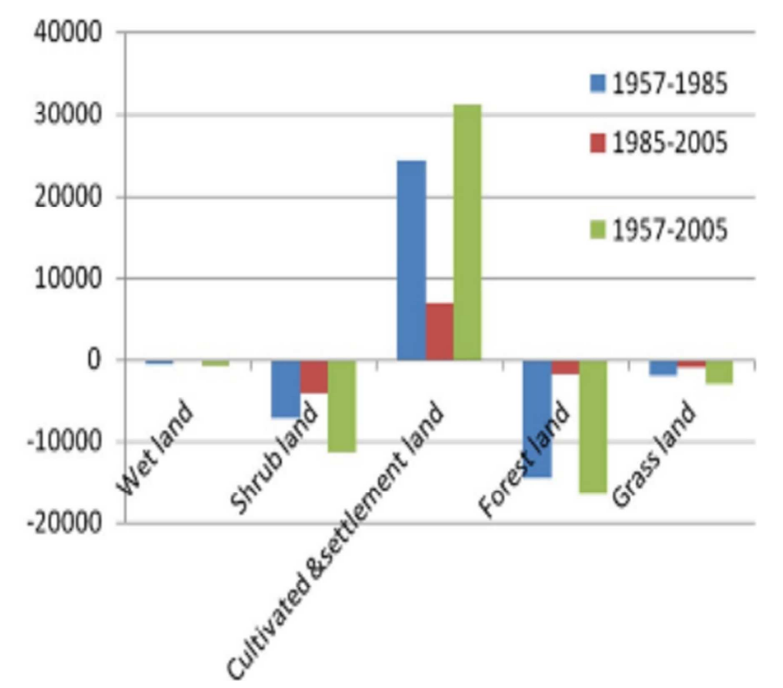

Figure 5. (A) Trends of the LULC dynamics in the Gumara watershed and (B) Rate of change in LULC dynamics in the Gumara watershed [85]. 
Table 4. Sample models of previous studies on Lake Tana and its basin.

\begin{tabular}{|c|c|c|}
\hline Models / Algorithms & Parameters used & References \\
\hline Supervised classification method and Linear regression and $t$ test & Temperature, Rain fall and Land cover and use dynamics & {$[62]$} \\
\hline Supervised classification and Statistical method (Mann Kendall test) & Land cover change, Rain fall and Stream flow & [71] \\
\hline $\begin{array}{l}\text { Soil and water assessment tool (SWAT), Statistical analysis (static land } \\
\text { use (SLU) and dynamic land use (DLU)) models }\end{array}$ & $\begin{array}{l}\text { LULC change, Surface runoff, Evapo-transpiration and peak } \\
\text { flow (hydrological response) }\end{array}$ & [80] \\
\hline Parameter Efficient Distributed (PED) model & Rain fall, Temperature and suspended sediment concentration & [94] \\
\hline Analytical Hierarchy process (AHP) approach & $\begin{array}{l}\text { Litho logy, lineaments, drainage density, rainfall, slop, LULC } \\
\text { and soils }\end{array}$ & [51] \\
\hline $\begin{array}{l}\text { Mass balance approach (modular three dimensional finite difference } \\
\text { groundwater flow model and penmans, Meyers and Thornwaites } \\
\text { methods) }\end{array}$ & $\begin{array}{l}\text { Precipitation, river in flow and outflow, evaporation and ground } \\
\text { water level, surface run o and rain fall }\end{array}$ & [15] \\
\hline $\begin{array}{l}\text { Had CM3 General Circulation model (GCM), statistical down scaling } \\
\text { model and HBV semi distributed rain fall, surface run o model }\end{array}$ & Temperature and precipitation & [1] \\
\hline
\end{tabular}

\section{Review out Puts}

Satellite image processing application for space science, remote sensing and earth observation research has made an amazing advancement over the past decades. The deduction is that today's models can sensibly reproduce many facets of past and present hydrological, atmospheric, climate, environmental conditions and space phenomena. Possible future changes have been modeled while taking account of uncertainties regarding both knowledge gaps and management options. Space generated knowledge is manifestly important to society for managing our natural resources, environment, space, and atmospheric phenomena and further work is needed. The space program, which started with basic science questions, and related programs throughout the past decades have now afforded several achievements that are of great practical importance such as Meteorological, atmospheric, space and remote sensing databases are available to the research community, partly as station data, including a growing number of freely available gridded datasets on decadal and centennial time scales. These freely available datasets powerfully back up the development of accurate forcing functions for modeling and statistical analysis. We better understand how large scale temperature, rainfall, LULC dynamics, stream flow, evapo-transpiration, surface runoff, suspended sediment concentration, precipitation, and river inflow outflow circulation affects the special and temporal variation of phytoplankton biomass of the lake and its gulf, the temporal trajectory change of the lake surface area, the climate change and the water balance of Lake at monthly and annually time scale. We have an improved understanding of the methods and models or algorithms used to study the lake and its basin. We have also improved our understanding from the direction of different sources of data sets and data sources which are applicable for the study of lake or sea surface dynamics, TSS dynamics of lake or sea surface, the turbidity of lake or sea surface, the impacts of LULC on lake or sea surface change and the link between lake or sea surface change and environmental changes.

\section{Research Gaps}

Notwithstanding the progress made in satellite image processing application for space science and remote sensing and related research in the last decades. In our review, we have seen different techniques of satellite imagery data processing with different statistical analysis methods and different classification models to study Lake Tana and its basin and to assess the colligate between the lake, the environment, and ecosystems in it and around it. But currently there are several research gaps on the lake and its basin (spatially on the lake). For example, while salinity is an elementary factor controlling the ecosystem of the lake, the current understanding of salinity changes is still very limited and future jutting of salinity is somewhat unsealed. In addition, more elaborated probes of regional precipitation and evaporation patterns (including runoff), atmospheric variability, highly saline water inflows, exchange between sub basins, circulation, and especially the long term dynamics of the lake surface, the link between LULC of the basin and environmental change of the lake and LULC dynamics of the basin from space. Such studies will require more advanced measurements, especially those made using deep machine learning, satellite image analysis, remote sensing techniques and direct measurements of turbulence.

\section{References}

[1] Abdo, K., Fiseha, B., Rientjes, T., Gieske, A., and Haile, A. (2009). Assessment of climate change impacts on the hydrology of gilgelabay catchment in Lake Tana basin, Ethiopia. Hydrological Processes: An International Journal, 23 (26): 3661-3669.

[2] Ahn, G.-C., Gordon, S. I., and Merry, C. J. (2014). Impacts of remotely sensed land use data on watershed hydrologic change assessment. International Journal of Geospatial and Environmental Research, 1 (1): 9.

[3] Alam, A., Rashid, S., Bhat, M. S., and Sheikh, A. H. (2011). Impact of land use/land covers dynamics on Himalayan wetland ecosystem. Journal of Experimental Sciences. 
[4] Alexakis, D., Grillakis, M., Koutroulis, A., Agapiou, A., Themistocleous, K., Tsa-nis, I., Michaelides, S., Pashiardis, S., Demetriou, C., Aristeidou, K., et al. (2014). GIS and remote sensing techniques for the assessment of land use change impact on flood hydrology: the case study of yialias basin in cyprus. Natural Hazards and Earth System Sciences, 14 (2): 413-426.

[5] Almazroui, M. (2011). Calibration of trmm rainfall climatology over Saudi Arabia during 1998-2009. Atmospheric Research, 99 (3-4): 400-414.

[6] Amsalu, A., Stroosnijder, L., and de Graa, J. (2007). Longterm dynamics in land resource use and the driving forces in the beressa watershed, highlands of Ethiopia. Journal of Environmental management, 83 (4): 448-459.

[7] Amsalu, T. and Addisu, S. (2014). Assessment of grazing land and livestock feed balance in gummara-rib watershed, Ethiopia. Current Agriculture Research Journal, 2 (2): 114122.

[8] Anteneh, W., Tewabe, D., Assefa, A., Zeleke, A., Tenaw, B., and Wassie, Y. (2015). Water hyacinth coverage survey report on Lake Tana biosphere reserve. Technical report, Technical report series Bahir Dar, Ethiopia. http://www. bdu. edu. et.

[9] Baulies, X. and Szejwach, G. (1998). LULC Data Requirements Workshop: Survey of Needs, Gaps and Priorities on Data for Land-use/land-cover Change Research, Barcelona, 11-14 November 1997. Number 3. Institute Cartogra c de Catalunya.

[10] Budiyanto, S., Tarigan, S., Sinukaban, N., and Murtilaksono, K. (2015). The impact of land use on hydrological characteristics in kaligarang watershed. International Journal of Science and Engineering, 8 (2): 125-130.

[11] Cao, Q., Yu, D., Georgescu, M., Han, Z., and Wu, J. (2015). Impacts of land use and land cover change on regional climate: A case study in the agro-pastoral transitional zone of china. Environmental Research Letters, 10 (12): 124025.

[12] Cardenal, S. J. P., Riegels, N., Bauer-Gottwein, P., Berry, P., Smith, R., Yakovlev, A., and Siegfried, T. (2011). Real-time remote sensing driven river basin modeling using radar altimetry. Hydrology and Earth System Sciences, 15 (1): 241254.

[13] Chaubey, I., Haan, C., Grunwald, S., and Salisbury, J. (1999). Uncertainty in the model parameters due to spatial variability of rainfall. Journal of Hydrology, 220 (1-2): 48-61.

[14] Chebud, Y. and Melesse, A. (2010). Stage level, volume, and time-frequency information content of Lake Tana using stochastic and wavelet analysis methods. Hydrology and Earth System Sciences Discussions, 7 (4): 5525-5546.

[15] Chebud, Y. A. and Melesse, A. M. (2009a). Modeling lake stage and water balance of Lake Tana, Ethiopia. Hydrological Processes: An International Journal, 23 (25): 3534-3544.

[16] Chebud, Y. A. and Melesse, A. M. (2009b). Numerical modeling of the groundwater flow system of the gumera subbasin in Lake Tana basin, Ethiopia. Hydrological Processes: An International Journal, 23 (26): 3694-3704.

[17] Chen, J. M. and Cihlar, J. (1996). Retrieving leaf area index of boreal conifer forests using land sat tm images. Remote sensing of Environment, 55 (2): 153-162.
[18] Chen, X., Yang, D., Chen, J., and Cao, X. (2015). An improved automated land cover updating approach by downscaled NDVI time series data. Remote sensing letters, 6 (1): 29-38.

[19] Chipman, J. W., Lillesand, T. M., Schmaltz, J. E., Leale, J. E., and Nordheim, M. J. (2004). Mapping lake water clarity with land sat images in wisconsin, usa. Canadian journal of remote sensing, 30 (1): 1-7.

[20] Choi, J., Hwang, M., Kim, G., Seong, J., and Ahn, J. (2016). Supporting the measurement of the United Nations sustainable development goal 11 through the use of national urban information systems and open geospatial technologies: a case study of South Korea. Open Geospatial Data, Software and Standards, 1 (1): 4.

[21] Chorowicz, J., Collet, B., Bonavia, F., Mohr, P., Parrot, J., and Korme, T. (1998). The tana basin, Ethiopia: intraplateau uplift, rifting and subsidence. Tectonic physics, 295 (3-4): 351-367.

[22] Collins, J. B. and Woodcock, C. E. (1996). An assessment of several linear change detection techniques for mapping forest mortality using multi-temporal land sat tm data. Remote sensing of Environment, 56 (1): 66-77.

[23] Dejen, E. (2003). Ecology and potential for sherry of the small barbs (Cyprinidae, Teleostei) of Lake Tana, Ethiopia.

[24] Deng, X., Zhao, C., and Yan, H. (2013). Systematic modeling of impacts of land use and land cover changes on regional climate: a review. Advances in Meteorology, 2013.

[25] Dessie, G. and Kleman, J. (2007). Pattern and magnitude of deforestation in the south central rift valley region of Ethiopia. Mountain research and development, 27 (2): 162-169.

[26] Dile, Y. T., Berndtsson, R., and Setegn, S. G. (2013). Hydrological response to climate change for gilgel abay river, in the Lake Tana basin-upper Blue Nile basin of Ethiopia. PloS one, 8 (10): e79296.

[27] Dimyati, M., Mizuno, K., Kobayashi, S., and Kitamura, T. (1996). An analysis of land use/cover change in Indonesia. International Journal of Remote Sensing, 17 (5): 931-944.

[28] Duan, Z., Gao, H., and Ke, C. (2018). Estimation of lake out flow from the poorly gauged Lake Tana (Ethiopia) using satellite remote sensing data. Remote Sensing, 10 (7): 1060.

[29] Esa, E. and Assen, M. (2017). A GIS based land suitability analysis for sustainable agricultural planning in gelda catchment, northwest highlands of Ethiopia. Journal of Geography and Regional Planning, 10 (5): 77-91.

[30] Fassnacht, K. S., Gower, S. T., MacKenzie, M. D., Nordheim, E. V., and Lille-sand, T. M. (1997). Estimating the leaf area index of north central wisconsin forests using the land sat thematic mapper. Remote sensing of environment, 61 (2): 229-245.

[31] Fu, B., Chen, L., Ma, K., Zhou, H., and Wang, J. (2000). The relationships between land use and soil conditions in the hilly area of the loess plateau in northern shaanxi, china. Catena, 39 (1): 69-78.

[32] Gao, F., Hilker, T., Zhu, X., Anderson, M., Masek, J., Wang, P., and Yang, Y.(2015). Fusing land sat and modis data for vegetation monitoring. IEEE Geosciences and Remote Sensing Magazine, 3 (3): 47-60. 
[33] Garc a, L., Rodrguez, D., Wijnen, M., and Pakulski, I. (2016). Earth observation for water resources management: current Use and future opportunities for the water sector. The World Bank.

[34] Garrity, S. R., Allen, C. D., Brumby, S. P., Gangodagamage, C., McDowell, N. G., and Cai, D. M. (2013). Quantifying tree mortality in a mixed species woodland using multi-temporal high spatial resolution satellite imagery. Remote Sensing of Environment, 129: 54-65.

[35] Gashaw, T., Bantider, A., and Mahari, A. (2014). Evaluations of land use/land cover changes and land degradation in dera district, Ethiopia: GIS and remote sensing based analysis. International Journal of Scientific Research in Environmental Sciences, 2 (6): 199.

[36] Gashaw, T. and Fentahun, T. (2014). Evaluation of land use/land cover changes in east of lake tana, Ethiopia. Environ. Earth Sci., 4 (11).

[37] Gashaye, D., Goshu, G., and Abraha, B. (2019). Temporal and spatial phytoplankton biomass dynamics in southern gulf of Lake Tana, northwestern Ethiopia. International Journal of Aquatic Biology, 7 (1): 1-8.

[38] Gebremicael, T., Mohamed, Y., Betrie, G., van der Zaag, P., and Teferi, E. (2013). Trend analysis of runoff and sediment fluxes in the upper Blue Nile basin: A combined analysis of statistical tests, physically based models and land use maps. Journal of Hydrology, 482: 57-68.

[39] Geist, H. J. and Lambin, E. F. (2001). What drives tropical deforestation. LUCC Report series, 4: 116.

[40] Getachew, H. E. and Melesse, A. M. (2012). The impact of land use change on the hydrology of the angereb watershed, Ethiopia. International Journal of Water Sciences, 1 (6).

[41] Gibson, P. J. and Power, C. H. (2000). Introductory remote sensing: Digital image processing and applications.

[42] Giuliani, G., Dao, H., De Bono, A., Chate-noux, B., Allenbach, K., De Laborie, P., Rodila, D., Alexandris, N., and Peduzzi, P. (2017). Live monitoring of earth surface (limes): A framework for monitoring environmental changes from earth observations. Remote sensing of environment, 202: 222-233.

[43] Haile, A. T., Rientjes, T., Gieske, A., and Gebremichael, M. (2009). Rainfall variability over mountainous and adjacent lake areas: the case of Lake Tana basin at the source of the Blue Nile River. Journal of applied meteorology and climatology, 48 (8): 1696-1717.

[44] Hautot, S., Whaler, K., Gebru, W., and Desissa, M. (2006). The structure of a Mesozoic basin beneath the Lake Tana area, Ethiopia, revealed by magneto telluric imaging. Journal of African Earth Sciences, 44 (3): 331-338.

[45] Holloway, J., Mengersen, K., and Helmstedt, K. (2018). Spatial and machine learning methods of satellite imagery analysis for sustainable development goals.

[46] Homer, C., Huang, C., Yang, L., Wylie, B., and Coan, M. (2004). Development of a 2001 national land cover database for the United States. Photogrammetric Engineering \& Remote Sensing, 70 (7): 829-840.

[47] Hwang, S.-A., Hwang, S.-J., Park, S.-R., and Lee, S.-W. (2016). Examining the relationships between watershed urban land use and stream water quality using linear and generalized additive models. Water, 8 (4): 155.

[48] Johnson, M. D., Hsieh, W. W., Cannon, A. J., Davidson, A., and Bedard, F. (2016). Crop yield forecasting on the Canadian prairies by remotely sensed vegetation indices and machine learning methods. Agricultural and forest meteorology, 218: 74-84.

[49] Kaba, E., Philpot, W., and Steenhuis, T. (2014). Evaluating suitability of modis terra images for reproducing historic sediment concentrations in water bodies: Lake tana, Ethiopia. International Journal of Applied Earth Observation and Geoinformation, 26: 286-297.

[50] Kebede, S., Travi, Y., Alemayehu, T., and Ayenew, T. (2005). Groundwater recharge, circulation and geochemical evolution in the source region of the Blue Nile River, Ethiopia. Applied Geo-chemistry, 20 (9): 1658-1676.

[51] Kindie, A. T., Enku, T., Moges, M. A., Geremew, B. S., and Atinkut, H. B. (2018). Spatial analysis of groundwater potential using GIS based multi criteria decision analysis method in Lake Tana basin, Ethiopia. In International Conference on Advances of Science and Technology, pages 439-456. Springer.

[52] Lambin, E. F., Geist, H. J., and Lepers, E. (2003). Dynamics of land-use and land-cover change in tropical regions. Annual review of environment and re-sources, 28 (1): 205-241.

[53] Lawler, J. J., Lewis, D. J., Nelson, E., Plantinga, A. J., Polasky, S., Withey, J. C., Helmers, D. P., Mart-inuzzi, S., Pennington, D., and Rade-lo, V. C. (2014). Projected land-use change impacts on ecosystem services in the United States. Proceedings of the National Academy of Sciences, 111 (20): 7492-7497.

[54] Li, Y., Fan, J., Hu, Z., Shao, Q., Zhang, L., and Yu, H. (2015). Influence of land use patterns on evapo-transpiration and its components in a temperate grass-land ecosystem. Advances in Meteorology, 2015.

[55] Lu, D. (2005). Aboveground biomass estimation using land sat tm data in the Brazilian Amazon. International Journal of Remote Sensing, 26 (12): 2509-2525.

[56] Lu, M., Chen, J., Tang, H., Rao, Y., Yang, P., and Wu, W. (2016). Land covers change detection by integrating object based data blending model of land sat and modis. Remote Sensing of Environment, 184: 374-386.

[57] M Muste PhD, P. (2010). Towards new types of water centric collaboration. Proceedings of the Institution of Civil Engineers, 163 (1): 39.

[58] McCartney, M., Alemayehu, T., Shiferaw, A., and Awulachew, S. (2010). Evaluation of current and future water resources development in the Lake Tana Basin, Ethiopia, volume 134. IWMI.

[59] Mekuriaw, S., Mekuriaw, Z., Taye, M., Yitayew, A., Assefa, H., and Haile, A. (2012). Traditional management system and farmer's perception on local sheep breeds (washera and farta) and their crosses in amhara region, Ethiopia. Livestock research for rural development, 24 (11).

[60] Memarian, H., Balasundram, S. K., Ab-baspour, K. C., Talib, J. B., Boon Sung, C. T., and Sood, A. M. (2014). Swat based hydrological modeling of tropical land-use scenarios. Hydrological sciences journal, 59 (10): 1808-1829. 
[61] Minale, A. S. (2013). Retrospective analysis of land covers and uses dynamics in gilgel abbay watershed by using GIS and remote sensing techniques, northwestern Ethiopia. Int. J. Geosci., 4: 1003-1008.

[62] Minale, A. S. and Rao, K. K. (2012). Impacts of land cover/use dynamics of gilgel abbay catchment of Lake Tana on climate variability, northwestern Ethiopia. Applied Geometrics, 4 (3): 155-162.

[63] Mohr, P. (1962). The geology of Ethiopia, 268 pp. Univ. Coll. Press, Addis Ababa.

[64] Morandini, G. (1940). Le caratteristiche di alcunilaghidell 'Africa oriental eitaliana. Ricci (tip.).

[65] Nigatu, Z. M., Rientjes, T., and Haile, A. T. (2016). Hydrological impact assessment of climate change on Lake Tanas water balance, Ethiopia. American journal of climate change, 5 (01): 27.

[66] Pardo-Iguzquiza, E. (1998). Optimal selection of number and location of rainfall gauges for areal rainfall estimation using geo statistics and simulated annealing. Journal of Hydrology, 210 (1-4): 206-220.

[67] Pathak, D., Shelhamer, E., Long, J., and Darrell, T. (2014). Fully convolution multiclass multiple instance learning. arXiv preprint arXiv: 1412.7144 .

[68] Piao, S., Yin, G., Tan, J., Cheng, L., Huang, M., Li, Y., Liu, R., Mao, J., Myneni, R. B., Peng, S., et al. (2015). Detection and attribution of vegetation greening trend in china over the last 30 years. Global change biology, 21 (4): 1601-1609.

[69] Poppe, L., Frankl, A., Poesen, J., Ad-masu, T., Dessie, M., Adgo, E., Deck-ers, J., and Nyssen, J. (2013). Geomorphology of the Lake Tana basin, Ethiopia. Journal of Maps, 9 (3): 431437.

[70] Ramakrishna, S. and Nasreen, S. A. A. N. (2013). An overview on water resources: pollution and nano materials. Future Medicine.

[71] Rientjes, T., Haile, A., Kebede, E., Man-naerts, C., Habib, E., and Steenhuis, T. (2011a). Changes in land cover, rainfall and stream flow in upper gilgel abbay catchment, Blue Nile basin Ethiopia. Hydrology and Earth System Sciences, 15 (6): 19791989.

[72] Rientjes, T., Perera, B., Haile, A., Reggiani, P., and Muthuwatta, L. (2011b). Regionalization for lake level simulation, the case of Lake Tana in the upper Blue Nile, Ethiopia. Hydrology and Earth System Sciences, 15 (4): 11671183.

[73] Rzoska, J. (1976). Lake Tana, headwaters of the Blue Nile. In The Nile, biology of an ancient river, pages 223-232. Springer.

[74] Setegn, S. G., Srinivasan, R., and Dargahi, B. (2008). Hydrological modeling in the Lake Tana basin, Ethiopia using swat model. The Open Hydrology Journal, 2 (1).

[75] Shen, M., Tang, Y., Chen, J., Zhu, X., and Zheng, Y. (2011). Influences of temperature and precipitation before the growing season on spring phenology in grass-lands of the central and eastern qinghaitibetan plateau. Agricultural and Forest Meteorology, 151 (12): 1711-1722.

[76] Shiferaw, A. and Singh, K. (2011). Evaluating the land use and land cover dynamics in borena woreda south wollo highlands, Ethiopia. Ethiopian Journal of Business and Economics, 2 (1).

[77] Song, C., Nigatu, L., Beneye, Y., Ab-dulahi, A., Zhang, L., and Wu, D. (2018). Mapping the vegetation of the Lake Tana basin, Ethiopia, using Google earth images. Earth System Science Data, 10 (4): 2033-2041.

[78] Su, Z., Lin, C., Ma, R., Luo, J., Liang, Q., et al. (2015). E ect of land use change on lake water quality in different buer zones. Applied Ecology and Environmental Research, 13 (2): 489-503.

[79] Tebebu, T., Abiy, A., Zegeye, A., Dahlke, H., Easton, Z., Tilahun, S., Collick, A., Kidnau, S., Moges, S., Dadgari, F., et al. (2010). Surface and subsurface flow effect on permanent gully formation and upland erosion near Lake Tana in the northern highlands of Ethiopia. Hydrology and Earth System Sciences, 14 (11): 2207-2217.

[80] Teklay, A., Dile, Y. T., Setegn, S. G., De-missie, S. S., and Asfaw, D. H. (2019). Evaluation of static and dynamic land use data for watershed hydrologic process simulation: A case study in gummara watershed, Ethiopia. Catena, 172: 65-75.

[81] Turner, B. L. and Meyer, W. B. (1994). Global land-use and land-cover change: an overview. Changes in land use and land cover: a global perspective, 4 (3).

[82] Wagner, P. D., Bhallamudi, S. M., Narasimhan, B., Kantakumar, L. N., Sudheer, K., Kumar, S., Schneider, K., and Fiener, P. (2016). Dynamic integration of land use changes in a hydrologic assessment of a rapidly developing Indian catchment. Science of the Total Environment, 539: 153-164.

[83] Weldegerima, T. M., Zeleke, T. T., Birhanu, B. S., Zaitchik, B F., and Fetene, Z. A. (2018). Analysis of rain-fall trends and its relationship with SST signals in the Lake Tana basin, Ethiopia. Advances in Meteorology, 2018.

[84] Worqlul, A. W., Maathuis, B., Adem, A. A., Demissie, S. S., Langan, S., and Steenhuis, T. S. (2014). Comparison of rainfall estimations by trmm $3 \mathrm{~b} 42$, mpeg and cfsr with ground-observed data for the Lake Tana basin in Ethiopia. Hydrology and Earth System Sciences, 18 (12): 48714881 .

[85] Wubie, M. A., Assen, M., and Nicolau, M. D. (2016). Patterns, causes and consequences of land use/cover dynamics in the gumara watershed of Lake Tana basin, northwestern Ethiopia. Environmental Systems Research, 5 (1): 8.

[86] Xian, G., Homer, C., and Fry, J. (2009). Updating the 2001 national land cover database land cover classification to 2006 by using land sat imagery change detection methods. Remote Sensing of Environment, 113 (6): 1133-1147.

[87] Yin, Z.-Y., Zhang, X., Liu, X., Colella, M., and Chen, X. (2008). An assessment of the biases of satellite rainfall estimates over the tibetan plateau and correction methods based on topographic analysis. Journal of Hydrometeorology, 9 (3): 301-326.

[88] Yuan, F., Sawaya, K. E., Loeelholz, B. C., and Bauer, M. E. (2005). Land cover classification and change analysis of the twin cities (Minnesota) metropolitan area by multi-temporal land sat remote sensing. Remote sensing of Environment, 98 (2-3): 317-328. 
[89] Zelalem, A., Belay, E., and Markos, A. (2018). Temporal trajectory analysis of lake surface area: Case study on Lake Tana, Ethiopia. The Ethiopian Renaissance Journal of Social Science and Humanities, 5 (1): 53-67.

[90] Zheng, D., Rademacher, J., Chen, J., Crow, T., Bresee, M., Le Moine, J., and Ryu, S.-R. (2004). Estimating above ground biomass using land sat $7 \mathrm{etm}+$ data across a managed landscape in northern wisconsin, usa. Remote sensing of environment, 93 (3): 402-411.

[91] Zhu, X., Helmer, E. H., Gao, F., Liu, D., Chen, J., and Lefsky, M. A. (2016). A flexible spatiotemporal method for fusing satellite images with different resolutions. Remote Sensing of Environment, 172: 165-177.
[92] Zhu, X. and Liu, D. (2014). Accurate mapping of forest types using dense seasonal land sat time series. ISPRS Journal of Photogrammetry and Remote Sensing, 96: 1-11.

[93] Zhu, Z. and Woodcock, C. E. (2014). Continuous change detection and classification of land cover using all available land sat data. Remote sensing of Environment, 144: 152-171.

[94] Zimale, F. A., Moges, M. A., Alemu, M. L., Ayana, E. K., Demissie, S. S., Tilahun, S. A., and Steenhuis, T. S. (2018). Budgeting suspended sediment fluxes in tropical monsoonal watersheds with limited data: the Lake Tana basin. Journal of Hydrology and Hydromechanics, 66 (1): 65-78. 